\title{
What Are and to What Avail Do We Study European International Law Traditions?
}

\author{
Peter Hilpold
}

\section{Some Definitions}

Discussions about "European International Law Traditions" have become more common in the last years even though still today many international lawyers might feel, in a first moment, uneasy with this concept. Many "traditional" international lawyers might be of the opinion that such a perspective could enter into conflict with the Universalist vocation or mission of modern international lawyers, and to some it might even call to mind long-overcome struggles and ambitions, politically incorrect ideas and ideologies.

We have, therefore, first of all, to ask whether it is correct to speak about "Legal Traditions". ${ }^{1}$ And what is "European"? What is "International"? And above all, what is a "Tradition"? Do "traditions" have any place at all in modern international law doctrine otherwise so eager to keep up with the most advanced legal doctrine or even to represent its avant-garde?

If we accept the concept of "tradition", do we have one or more of such traditions? And if we opine for the latter, in which relationship do they stand reciprocally? It becomes immediately evident that this ramification of the discussion

The original version of this chapter was revised. A correction to this chapter can be found at https://doi.org/10.1007/978-3-030-52028-1_13

\footnotetext{
${ }^{1}$ The whole discussion about "Legal Traditions" was strongly influenced by the ground-breaking works by Patrick Glenn. See in particular Patrick Glenn, Legal Traditions of the World (a book that was received in academia both with high praise and sharp criticism, $2^{\text {nd }}$ edition, Oxford University Press 2006). See Thomas Duve, 'Legal traditions: A dialogue between comparative law and comparative legal history’ (2018) 6 Comparative Legal History 20.
}

\author{
P. Hilpold $(\triangle)$ \\ University of Innsbruck, Innsbruck, Austria \\ e-mail: Peter.Hilpold@uibk.ac.at
}


leads us to the issue of "Comparative International Law", a field of academic research that holds considerable promise notwithstanding continuing (although diminishing) opposition against its foundations. This introductory text will come back repeatedly to the subject of comparative international law as this branch of law is surely of pivotal importance for any inquiry into international law traditions.

As to the "Europeanness" of this approach, it is well known how much European lawyers (and also politicians) are struggling with how to define and to circumscribe this concept. It has been said that attempts could be made to interpret this term, for example in a geographic, political, communal, economic, ethno-religious, essentialist, semantic or philosophical sense, but none of these approaches can be considered as exhaustive or fully convincing. ${ }^{2}$

Recently it has instead been suggested not to look for fully fledged Europeanness, a condition probably too demanding to prove but for "traces" of such Europeanness reflecting the cultural origin of the respective authors. ${ }^{3}$

Defined this way, Europeanness becomes, of course, a rather subjective characteristic, where the "critical mass" starting with which Europeanness can be seen as given lies, to a considerable extent, in the eye of the beholder. Furthermore, such an approach will lead to a situation where Europeanness will become in future ever more difficult to discern and to distinguish from, say, "Americanness", in particular in view of the fact that academic institutions are now cooperating far more closely than was the case only a few decades ago. ${ }^{4}$

As to the element of "Internationality", again misunderstandings might arise in a global discussion. In fact, as has been evidenced in detail by David Kennedy, in the United States the concept of international law has been delimitated quite differently than in Europe, with "blurry boundaries", for example, between public international

\footnotetext{
${ }^{2}$ See Outi Korhonen, 'Innovative International Law Approaches and the European Condition' in José María Beneyto/David Kennedy (eds.), New Approaches to International Law (T.M.C. Asser Press, The Hague, Netherlands, 2012).

${ }^{3} I$ Ibid., 210 and 220. Korhonen describes this "identity-defining" and "identity-ascribing" process as follows:
}

If we relax our attitude, we could perhaps summarize that a range of innovative disciplinary writings from Kennedy to Marks and Chinkin, from Koskenniemi to Hoffmann, from Simpson and Simma to Allot, and others is more or less 'European'. If we dissect the texts, idioms and subtexts, we find traces of the European, which we cannot, however, in any way determine or fix without inserting the personal-political of the specific authors and their audiences into the 'algorithms' - the cultural geography of origin being one lesser figure among them. Ibid., 220.

${ }^{4}$ In this context we would ask the following question: A Professor teaching, say, both in Paris as at the New York University, starting from which moment does he switch from being European to becoming American? Or can he be both and do we then have to distinguish between single publications or even single parts of his publications? See in this context also Michael Wood, 'A European Vision of International Law: For What Purpose?' in: Hélène Ruiz Fabri et al. (eds.), Select Proceedings of the European Society of International Law (vol. I, 151-163 who speaks of "Europeanized Americans" and "Americanized Europeans" (at 157) 2008). 
law and private international law. ${ }^{5}$ In Europe, traditionally, however, this was not a real problem as there a widely uniform concept of "Public International Law" both in practice and in theory applies. ${ }^{6}$ This may change in future as international law theory more and more shifts its focus from interstate relations to the internal level, as "Global Administrative Law" (GAL) more and more sets rules and standards for situations that not long ago were exclusively part of the national "domaine réservé".

Also the concept of "legal traditions" needs some further clarification. In the past, comparative analysis was prevailingly undertaken with reference to "legal families", a concept still in use but in decline as it is closely associated with the idea of legal nationalism. ${ }^{7}$ Instead, the concept of "legal traditions" is looking beyond these dated, static dividing line paying tribute also to influences attributable to a "transnational law" ${ }^{\prime 8}$ that is taking more and more shape.

For a definition of this concept, reference is often made to John Henry Merryman's "The Civil Law Tradition: An Introduction to the Legal Systems of Europe and Latin America" (1969, fourth edition 2018). According to this author, a legal tradition is:

a set of deeply rooted, historically conditional attitudes about the nature of law, about the role of law in the society and the polity, about the proper organization and operation of the legal system, and about the way law is or should be made, applied, studied, perfected, and taught. ${ }^{9}$

Two elements seem to be pivotal in this definition: legal traditions are "deeply rooted attitudes", and they are "historically conditional". In deference to the first element, the contributions to this book try to explain existing national legal traditions as the product of the broader cultural environment where they have developed and from which they are the offspring. What may appear to be awkward in these legal traditions if examined in an isolated manner becomes far better understandable if looked at as an element of a broader cultural reality. Similar considerations apply as to the second element mentioned: considering the historical development of legal provisions presently in force may open up a perspective that allows us to understand legal settings that might otherwise appear incomprehensible, arbitrary and perhaps even pointless or nonsensical.

\footnotetext{
${ }^{5}$ See David Kennedy, 'The Disciplines of International Law and Policy' (1999) 12 Leiden Journal of International Law, 19. This problem becomes further accentuated in the "Invisible College of International Lawyers", so famously portrayed by Oscar Schachter. See Oscar Schachter, 'The Invisible College of International Lawyers' (1977) 72 Nw.U.L. Rev. 217.

${ }^{6}$ This holds true even though the actual teaching obligations of International Law Professors vary considerably. For example, in Italy International Law Professors have to teach Public International Law and Private International Law. In Germany Public International Law is regularly taught together with (German) Public Law and European Law.

${ }^{7}$ See H. Patrick Glenn, 'Comparative Legal Families and Comparative Legal Traditions' in: Mathias Reimann/Reinhard Zimmermann (eds.), The Oxford Handbook of Comparative Law (2006) 424.

${ }^{8}$ For the foundations of this approach see Philip C. Jessup, Transnational Law (1956).

${ }^{9}$ John Henry Merryman and Rogelio Pérez-Perdomo, The Civil Law Tradition: An Introduction to the Legal Systems of Europe and Latin America (2018) 2.
} 
It has been said that legal traditions are the "historical underpinnings of modern law", ${ }^{10}$ where modern law is not only the last sequence of a historical development, but according to Harold J. Berman and Edmund Burke, modernity and history are rather interwoven in a continuous dialogue and a "partnership of generations". 11

Against these considerations, it could be remarked that international law is $e x$ definitione universal, a norm system created by the state community and for the state community. Consequently, it might be counterintuitive and counterproductive to look for a genealogical pedigree of single norms. Might looking back constitute a step backwards in the legal development? Might a "re-nationalization" of international law constitute a further contribution to the much-lamented fragmentation of international law, ${ }^{12}$ a road to the tower of Babylon where the common language so intensively propagated and cultivated in the past would again be exposed to the peril of going lost or at least be weakened so that communication across national borders could be further complicated? This project was premised on the proposition that such worries are not justified and that, on the contrary, a contribution could be given for a better understanding of international law, both with regard to its main elements and in the international dialogue about its core characteristics. ${ }^{13}$

As it is often said, the main purpose of any comparative study of law is to know and to understand one's own legal order better. ${ }^{14}$ A similar, somewhat modified proposition has been asserted as to the relationship between national law and international law. According to William Butler, comparative studies of one or more legal systems or families of legal systems "can contribute an indispensable perspective to our understanding of international law". ${ }^{15}$ I would specify that this holds particularly true as to our national understanding of international law and as to the differences in the way we approach international law issues. And we have to consider that different parts of the national legal order are differently related to international law. While some elements of national legal orders are (or have been in the past) largely independent from international law (this is the case-or has been the

\footnotetext{
${ }^{10}$ See Thomas Duve (supra, note 1), 21.

${ }^{11}$ See in this sense Harold J. Berman, 'The Western Legal Tradition in a Millennial Perspective: Past and Future' (2000) 60 La. L. Rev. 740. Referring again to Edmund Burke, Reflections on the Revolution in France, 1790. See also Thomas Duve (supra, note 1), 22.

${ }^{12}$ Fragmentation of International Law: Difficulties from the Diversification and Expansion of International Law, Report of the Study Group of the International Law Commission (ILC), finalized by Marti Koskenniemi, UN Doc. A/CN.4/L/682 (2006).

${ }^{13}$ As it was aptly said by Harold J. Berman: "We need a long time-perspective in order to understand the long-term character of the fundamental changes that are now taking place and in order to anticipate a long-term future." Supra, 11, 741. And further: "[ . . ] what we remember of the past is based on our anticipations of the future, and our anticipations of the future are based on our memories of the past." Ibid., 763.

${ }^{14}$ See Aalt Willem Heringa, Constitutions Compared (5 $5^{\text {th }}$ ed., 2019) 1.

${ }^{15}$ See William E. Butler, International Law in Comparative Perspective (1980) 2.
} 
case until recently - for large parts of administrative law), ${ }^{16}$ others are very close to international law (such as the constitutional provision on the incorporation of international law or the broad field of human rights provisions). The closer national provisions are to international law, the more a comparison of the relevant provisions will tell us about what our understanding of international law is. But also those provisions of national law that are not immediately related to international law can give us, in a comparative perspective, useful hints on how international law issues are approached by the various states as thereby general visions of legal theory and legal philosophy emerge that apply to a legal order as a whole. And legal orders comprise, according to the monist approach, both national law and international law-they merge to a single legal order amenable to a unified act of interpretation.

\section{The European Perspective}

Let us now turn closer to the ends of this specific project in a narrower sense. But before we enter into a more detailed exposition about what this project is, let us first say some words about what it is not.

It is not intended here to engage in a broader discussion about the role that European international law has in the present international legal order or had there in the past. ${ }^{17}$ Even less, it is intended to attribute a sort of moral pre-eminence to European international law, however it is to be defined.

As is well known, the relevant discussion, whether a European international law exists at all and what its influence on universal international law is, is often conducted in a rather acrimonious tone with some authors sustaining (or at least implicitly assuming) that universal international law has been prevailingly shaped by

\footnotetext{
${ }^{16}$ On the subject of the "GAL" (Global-Administrative Law)-studies see Sabino Cassese (ed.), Research Handbook of Global Administrative Law (Cheltenham 2016).

${ }^{17}$ See Arnulf Becker-Lorca, 'Eurocentrism in the History of International Law' in Bardo Fassbender/Anne Peters (eds.), The Oxford Handbook of the History of International Law (2012) 1034-1057. See also Hélène Ruiz Fabri, 'Reflections on the Necessity of Regional Approaches to International Law Through the Prism of the European Example: Neither Yes nor No, Neither Black nor White' (2011) 1 Asian Journal of International Law 84: “[. . .] Europe's past or that of a certain number of European countries being what it is, the issue [of an European approach to International Law] quickly sparks off the suspicion that the aim is to reflect on the device for a renewed imperialism." Ibid., p. 84.
} 
European (Western) international law, ${ }^{18}$ while others are denying such an influence or are contesting the existence of such a European international law altogether. ${ }^{19}$

The political agenda often associated with these propositions further compounds the problem and makes it difficult to find a standpoint that would generally qualify as neutral and objective. According to the position taken here, it cannot be denied that the formation of international law has been predominantly influenced by European (Western) states, and still today concepts of European origin occupy a prominent place in universal international law. Nonetheless, it has also to be pointed out that for a long time, the formation of international law has become a truly global project. ${ }^{20}$ Even concepts that once have been of European origin have been taken up, transformed and further developed in other regions, only to return to Europe as part of universal international law with a largely modified meaning. The formation of customary international law has necessarily to consider universal practice. ${ }^{21}$ As to multilateral treaties in the UN era, they are typically negotiated in global conferences or are elaborated within the International Law Commission, and thereby the global community becomes institutionally involved. ${ }^{22}$

Thus, while European (and further Western) countries have provided-to a considerable extent-structure and terms for the language in which international law is spoken and developed, its content is formed in a comprehensive global dialogue.

\footnotetext{
${ }^{18}$ See, for example, Colin B. Picker, 'International Law's Mixed Heritage: A Common/Civil Law Jurisdiction' (2008) 41 VandJTransnatlL 1083: “[...] it is to say that the dominant character of modern international law is Western". Ibid., 1099.' Or, a few years earlier, Martti Koskenniemi, 'International Law in Europe: Between Traditional and Renewal' (2005) 16 EJIL 113: "One can do international law better or worse, but the criteria of excellence have been set by Europeans: Cicero and Roman Law, Catholic intellectuals, Vitoria in the sixteenth or Louis le Fur in the twentieth century, protestant activists, Hugo de Groot in the seventeenth, or Johann Caspar Bluntschli in the nineteenth century." Ibid., 114.

${ }^{19}$ See Alexander Orakhelashvili, 'The Idea of European International Law' (2006) 17 EJIL 315 who relies i.a. on natural law to argue that International Law has been universal since its inception. Ibid., p. 316. While it might be true that natural law informed legal thinking since ancient times we have, however, also to consider that the effective meaning of natural law varies from region to region and from epoch to epoch. It is an illusion to think that natural law as such is universal and uniform in all details. On the other hand, as will be shown below, it can be argued that there are some basic principles that can be considered as really universal and present in all periods and times.

${ }^{20}$ See in this context Arnulf Becker-Lorca, Mestizo International Law: A Global Intellectual History (1842-1933), (CUP: Cambridge 2014) who demonstrates how international lawyers from what was then considered to be the periphery of the Western world managed to contribute to the shaping of international norms that became thereby truly universal. Important elements of what we often consider Western norms universalized by the imperial powers in reality is therefore "mestizo law" influenced by the "periphery" long before the concept of nations had become a structural principle of International Law.

${ }^{21}$ True, the "persistent objector" has to be considered here but this issue is, if at all, of limited practical importance. See, i.a., Patrick Dumberry, 'Incoherent and Ineffective: The Concept of Persistent Objector Revisited' (2010) 59 ICLQ 2010779.

${ }^{22}$ See on this recently Simon Chesterman et al. (eds.), The Oxford Handbook of United Nations Treaties (OUP: Oxford 2019) 23ff.
} 
This finding should not, however, obscure the view for two elements that appear to be very important for the further discussion of this book's overarching topic:

- The fact that international law is global does not exclude specific regional inputs that might remain discernible as to their original provenience over quite a long time.

- Even if a rule has consolidated globally and even if its genealogical roots are gone out of sight, it might still be the case that individual states or state blocs develop an original perspective towards this rule. To a certain extent, international rules might be "re-nationalized" in the sense that a specific meaning is given to it. While such a situation is prone to lead to international controversies, the ensuing dispute might hold on for a considerable period.

- And it is not excluded that a "particular" or a "regional" meaning will eventually become the prevailing one.

Pursuant to these considerations, the goal of this collective writing is at the same time a modest and an ambitious one.

It is modest in the sense that it does not try to isolate what is "European" in international law and subsequently endeavour to explain to what extent European international law traditions have influenced present (global) international law as a whole. Such a project would be of an enormous reach and probably even unfeasible.

It remains, however, ambitious in the sense that it looks for specific national approaches towards international law that are, already for geographical reasons, at the same time European traditions. These studies are premised on the assumption that there is regularly something particular and peculiar in how single European states approach, interpret and apply international law. ${ }^{23}$

These specifics may again relate to history or culture or may be idiosyncratic for a certain national academic community. ${ }^{24}$ In any case, they determine what "(international) law in action" is, and eventually they may be conducive also to a new "(international) law in the books".

They can be addressed in different ways, and in fact, as the readers of this book will note, the authors have chosen widely diverging approaches to identify and to explain the particularities of their national legal orders' perspective on international law. These differences are partly due to the different weight that individual European countries have on the international scene, and this weight may again diverge in a historical perspective so that, in some cases (for example with regard to Austria), it

\footnotetext{
${ }^{23}$ David Kennedy coined a simple but incise formula to give expression to this situation of different attitudes toward International Law on a worldwide scale. For him, International Law is "different in different places". See Kennedy (n 5) 17.

${ }^{24}$ With regard to the American vantage point see the fitting considerations by Mark W. Janis, 'Comparative approaches to the theory of international law' (1986) 80 ASIL 152:
}

We do not approach international law in the same way as Americans did in 1914 or in 1861 or in 1783. Nor do we now approach international law in the same way as do other nations. The French and other Western European countries, the Soviet Union and the other Communist States, India and the other developing countries of Asia, Africa and Latin America, all have distinctive national international law traditions. 
seemed appropriate to give more space to considerations regarding a more distant past or to aspects of the academic discussion rather than to a technical exposition of governmental measures presently in force.

In other cases (such as in that of Germany), both due to the relevance of this country on the international level and the academic specialization of the authors chosen, the decision was taken to address one specific material subject (international economic law, of course alongside a further general contribution on the German international law tradition) where arguably a considerable country-specific influence on the development of that area of international law had come to bear.

To what end were these studies undertaken? A first impression could be that they give an account of the historic development of international law from the vantage points of different European countries. A series of names of past luminaries is thereby revived, and at least to this author it was impressive to see how relevant many of their ideas and visions still are today.

But when undertaking these studies, the proposition was that there is much more that can be gleaned from such an endeavour. In fact, this could be seen as an exercise in comparative law. Dealing with international law issues in a comparative perspective may still not be very common, but, as already hinted at, the endeavours of this kind undertaken so far reveal the enormous potential lying therein. ${ }^{25}$

In fact, it cannot be denied that states are approaching international law issues in quite a different way, and this is reflected in practically all present international crises. While primary attention is thereby usually devoted to the "great players", a closer look at the behaviour of European governments when issues with immediate repercussions on their states are at stake, for example in the field of migration or when sanctions against third countries are discussed, reveals often a sort of "European standpoint" and in numerous times also quite consistent divides also between European countries. These attitudes follow regularly a specific pattern that may also relate to a particular national international law tradition. ${ }^{26}$ A greater awareness for these traditions may render the behaviour of governments more predictable and international governance more calculable. But there is much more potential gain in looking into European international law traditions.

The whole of Europe is now in a difficult process of re-assertion in a multi-polar world where Europe is losing its competitive edge due to declining economic power, its shrinking percentage of world population, the graying of its population and the inability of the European Union - and not to mention the continent as a whole- to speak with one voice or to build up at least some political weight.

This situation ended up in what may be called a political inferiority complex creating a self-perception of "near-irrelevance" on the international scene. A rediscovery of the many traces of Europeanness of international law might nudge

\footnotetext{
${ }^{25}$ See, for example, William Butler (ed.), International Law in Comparative Perspective (1980) or Colin B. Picker (supra, note 18).

${ }^{26}$ According to some authors (see Dana Zartner Falstrom, 'Thought Versus Action: The Influence of Legal Tradition on French and American Approaches to International Law' (2006) 58 Me. L. Rev. 292, cited according to Colin B. Picker (supra, note 18, 1089), legal traditions are pivotal to explain states' legal response to international crises.
} 
Europe to come out of the corner it has manoeuvred itself into and motivate the countries of this continent to reassume more actively the dialogue with the rest of the world whose legal setting it has so extensively influenced. This influence might not always have been positive, but also Europe has learnt from these experiences in an interaction that for long has become global and equal.

\section{The Single Contributions to This Book}

If we turn our view to the individual contributions, already the first one written by Christian Tomuschat evidences the dimension of this challenge to write about single national contributions to international law. It reveals, however, also that this challenge can be mastered and that highly interesting insights can result from such an endeavour. The author demonstrates that the German Basic Law (Grundgesetz) endorses the general rules of international law in a spirit of optimistic world solidarity, which is in strict contrast to an understanding of international law as "external state law", a concept that German philosophers (Hegel) and legal thinkers (see Jellinek, Zorn) have predominantly contributed to develop. Tomuschat highlights Germany's trust in international law (in strict contrast to the situation in the period between 1933 and 1945), strongly supported by the German international law academia. He ends his article with a plea for an even more active foreign policy in the service of peace, human rights and the international rule of law.

Heribert Franz Köck gives a broad overview of the "Austrian School of International Law". He again starts with the consideration that it is difficult to identify a typical national approach to international law, but he also manages to identify some fundamental contributions that Austrian legal doctrine has given to the international law doctrine as a whole. Mostly and pre-eminently, this doctrine is associated with the name of Hans Kelsen and his Vienna School of legal theory, but Professor Köck, himself an eminent representative of the modern natural law school, highlights the contributions by Alfred Verdross and his concept of justice, strongly influenced by natural law ideas, which has given a lasting impact on present-day international law. According to Köck, many basic concepts of international law, in particular as they find expression in UN law, are based on these ideas. He demonstrates that Verdross' ideas are living on in the "Austrian School of International Law" and far beyond.

The reader of Carlo Focarelli's contribution will learn a lot of the development of Italy's international law academia—but at the same time get acquainted with Italian literature, history and philosophy. Focarelli demonstrates how closely national legal traditions are connected with the general culture of the respective country. The lawyer who wants to become really domestic with a specific national legal tradition will have to adopt a very broad perspective and not limit his studies to legal norms and texts.

As to the Italian manuals of the past, which in the meantime, outside Italy, might have become all but forgotten, ${ }^{27}$ it might be revealing for the reader to see how

\footnotetext{
${ }^{27}$ But they are still cited in the dominant treatises such as Oppenheim's International Law.
} 
modern many of their insights are, even if they have been formulated in the nineteenth or in the early twentieth century. It suffices here to refer, for example, to Pasquale Fiore's (1837-1914) studies on what we would call today "erga omnes obligations". The analysis of Rolando Quadri's (1907-1976) studies calls into mind the acts of modern superpower politicians when Focarelli cites Quadri's underlying assumption according to which "the law is a product of the strongest who act uti universi", but at same time he quotes Quadri as stating that "no state in the world, not even the strongest, is legisbus solutus".

As to the "literary part" of Focarelli's contribution, he identifies in the works examined two "key Italian attitudes": "realism" and "humanism". Focarelli ably demonstrates that the same aspects can be identified in the attitude of Italian lawyers towards international law.

Andrea Hamann undertakes a broad enquiry into the concept of "traditions in International Law" in general and in France in particular. As an academic of German provenience and full legal education in France, she is best prepared to adopt an "inside" as an "outside" perspective. She analyzes academic trends and attitudes of a country that has given so important contributions to the development of international law on both practical and theoretical levels, whose language has once been the lingua franca of international law but which, in the meantime, has lost much of its clout. On the practical level, this results from a massive shift in the power relations on the political landscape, while on the academic level this problem is also associated with the diminishing relevance of the French language on the international scene. Furthermore, also the structure of the French academia might have influenced this development. Andrea Hamann pinpoints in her contribution some of the most conspicuous traits of the French international law academia that are peculiar to this country-and nonetheless evoke associations with similar situations in other European countries. ${ }^{28}$

It has already been pointed out that the concept of "traditions of International Law" means different things to different people. It might not be surprising that those international lawyers who are particularly wary of preserving the unity of international law have the most problems with speaking about "national traditions". The British practitioner Sir Michael Wood is one of these lawyers. He opposes any attempt to "compartmentalize" international law study and practice into "national" approaches and to imagine a "divisible college of international lawyers". These

\footnotetext{
${ }^{28}$ This is in particular true with regard to the central importance attributed to International Law chairs in the capital, in this case Paris. While it can be said that Universities (and thereby academic institutions where International Law is taught) in all capitals of European states enjoy a somewhat privileged position, in some countries, like in France but also in Italy, this position of pre-eminence is more accentuated.

Interesting comparisons can also be made with regard to the position government representatives have within the national International Law academia. While Andrea Hamann writes that in France this position is a rather prominent one, to a certain degree this is also the case in other European countries (such as in Austria where, for example in Graz, specific chairs for "practitioners" of International Law and EU Law - up to this moment coming from Ministries in Vienna - have been created.
} 
warnings are, of course, justified, and any international lawyer who would seriously try to artificially fragment international law with the intent to advocate a national tradition perhaps retained as superior or more advanced in respect of other national traditions would commit a capital sin: he would saw the branch on which he is sitting. Needless to say, this is usually not the intent of that part of the international law academia that engages in studies on international law traditions.

Wood wants to rule out any doubt in this regard, and for this reason he speaks more modestly of "British contributions" in public international law. At the end, the choice of this wording is fully in line with the overall philosophy that undergirds this research project. In fact, the basic idea is that there are some distinct national contributions to international law, some national attitudes that are distinct in respect of those of other nations, and identifying (but not necessarily emphasizing) them might contribute to a better understanding of the international law order as a whole and to devising lines of development that might identify future advancements in international law.

Anybody somewhat familiar with international law as a science might have no difficulties in underwriting the empirical perception by the author that the United Kingdom has a long tradition of being the source of specifically fine and important contributions to international law studies, may they originate from native people or from academics coming to the UK for whatever reason. Wood attempts to explore what might have been the cause for such a leading role the UK is exercising in this field. He sees several reasons for British lawyers being able to contribute so strongly to this discipline, and he refers in this context, for example, to the common law training of its lawyers as this might have given way to a "strong predilection for the development of the law through decided cases and specific instances" (Robert Jennings). One further fact he refers to lies in the circumstance that many leading British academics have also been practitioners before English and international courts. Consequently, international law is taken very seriously in the UK, and thereby a notable influence is exercised on the development of international law on a global scale. By strengthening international law as such, the UK contributes to more respect for this order also by other nations.

Jan Wouters and Nina Pineau have provided an overview of the Belgian and Dutch traditions in international law. And there was much to tell, already in view of the fact that the "father of International Law", Hugo Grotius, comes from this region. The authors analyze further in their text the contributions by Gustave Rolin-Jaequemyns, Emile de Laveleye, Edouard Descamps, Charles de Visscher, Cornelis van Bijnkershoek, Tobias Michael Carel Asser, Bert Röling, Henry Schermers, Pieter Kooijmans as well as many other also contemporary authors. How was it possible that authors of two rather small countries could exert such an important influence on the development of international law literature? Wouters and Pineau provide an interesting explanation for this: both countries have been neutral for a long period of time, and this created an atmosphere that allowed academics and practitioners to develop a humanist, pacifist and Universalist perspective on international law.

Astrid Kjeldgaard-Pedersen and Jakob v.H. Holtermann take a square look at the "Scandinavian Perspective". They refer to the difficulties in identifying a "Nordic approach" that should apply both to practice and to theory. At the same time, however, they evidence that talking about a "Nordic approach" has a strong 
aspirational value where this "mythic north" stays for a strong commitment to democracy, rule of law and the protection of human rights. In this sense, the identification of a national (or regional) legal tradition can be important not only for what it actually is but also for what it stands for in theory and imagination.

The following contribution by Lauri Mälksoo on the "Russian Concept of International Law as Imperial Legacy" might meet with particular attention by this book's readers as it concerns the approach to international law by a powerful state at the geographical margins of Europe which has stood for a long time in conflict with the Western bloc of European states and which again continues to challenge traditional Western values, for example with regard to the annexation of Crimea $^{29}$ or in relation to human rights before the European Court of Human Rights. For Lauri Mälksoo, this particular attitude towards international law can be explained by Russia's past as an empire and the deep-rooted fears by the Russian political elite that abandoning the Empire would mean abandoning Russia herself. This attitude is reflected directly by Russian academic writing as internationalists in Russia often see their main role in supporting the government in its foreign policy with legal arguments. ${ }^{30}$

The following two contributions by Stefanie Bock and Ernst-Ulrich Petersmann again turn to Germany, but they are focused, differently than the contribution by Christian Tomuschat, on a specific material subject.

Stefanie Bock writes on the German contribution to the creation of international criminal justice. She shows that the highly developed German criminal justice doctrine could in fact give an outstanding contribution to the development of this field, and up to this day, important initiatives to further develop international criminal justice are coming from Germany. It can therefore be said that at least in this field a specific national legal tradition had finally exercised determinant influence on the international level.

The final contribution by Ernst-Ulrich Petersmann examines what the influence was of German-speaking countries on the development of international economic law. Undoubtedly, this influence was remarkable (even though it might not have been so far-reaching as that of German criminal law doctrine on international criminal law). And there are many levels on which this influence was exercised: inside the European Union (Austria and Germany), in the European Economic Area (Liechtenstein) and in the European Free Trade Area (Switzerland).

\footnotetext{
${ }^{29}$ See Peter Hilpold, 'Ukraine, Crimea and New International Law: Balancing International Law with Arguments Drawn from History' (2015) 14 Chinese JIL 237.

${ }^{30}$ Lauri Mälksoo refers in context to the frank statement by O.N. Khlestov, 'Rossiiskaya doktrina mezhdunarodnogo prava' (2013) 58 Evraziiskii iuridicheskii zhurnal 19.

For a disillusioning portray of the situation within the Russian International Law academia see also Maria Issaeva, 'A Quarter of a Century on from the Soviet Era: Reflections on Russian Doctrinal Responses to the Annexation of Crimea' in Wladyslav Czaplinski (ed), The Case of Crimea's Annexation under International Law (Warsaw 2017) 155-179. She furnishes a critical picture of the Russian International Law academia characterized by the dominance of a hierarchical, closed and self-complacent academic society, elements, however, not unknown also to Western International Law academic societies.
} 
Due to their constitutional "common market" and monetary and fundamental rights protection, these countries share common traditions of supplementing (1) private and (2) public law regulations of the economy by (3) economics-driven, multilevel economic regulation (e.g. of transnational common markets, international trade and investment law); (4) multilevel administrative law (e.g. on transparency and legal accountability of international economic organizations); and (5) multilevel constitutional protection of transnational rule of law and fundamental rights of citizens (e.g. by European courts protecting common market rights and fundamental rights). The article describes regulatory challenges of Europe's microeconomic "common market constitutions", macroeconomic "monetary constitution" and "social market economies", which differ from the hegemonic, interest-group-driven US neoliberalism, the mercantilist "economic security order" advocated by US President Trump in response to the geopolitical rivalry from China and the totalitarian state capitalism promoted inside China.

Of course, one might find some elements of ordo-liberalism also in GATT law and in WTO law, but here the picture becomes more diffuse. What recently has been stated about the universality of international economic law proves again to be right: there are some universal elements in international economic law, but for the rest, "states want to retain control". 31 As far as Petersmann writes about a constitution of international economic law, he writes also about his own lifelong academic project. While also many others have participated in this endeavour, Professor Petersmann's contribution in this field was surely of paramount importance. ${ }^{32}$

\section{Looking Forward}

No doubt, it would be interesting to embark in an even more comprehensive comparative project that should consider the vast majority, if not all, of European international law traditions. We can return here to the introductory statement according to which the main purpose of comparative analysis in public law is to know one's own legal order better. ${ }^{33}$ Comparing various international law traditions should provide, first of all, further insight into the national order that the reader is most acquainted with and answer the questions on how open that respective order is

\footnotetext{
${ }^{31}$ See in this sense Laurence Boisson de Chazournes, 'International economic law and the quest for universality' (2019) 32 LJIL 401, 413.

${ }^{32}$ See also the Festschrift dedicated to Ernst-Ulrich Petersmann with a series of writings by academics from all over the globe aiming at paying tribute to the seminal contributions of the jubilee in this field: Marise Cremona, Peter Hilpold, Nikolaos Lavranos, Stefan Staiger Schneider and Andreas R. Ziegler (eds.), Reflections on the Constitutionalisation of International Economic Law (Liber Amicorum for Ernst-Ulrich Petersmann, Brill/Martinus Nijhoff: Leiden/Boston 2014).

${ }^{33}$ See also Karl-Peter Sommermann, Die Bedeutung der Rechtsvergleichung für die Fortentwicklung des staats- und Verwaltungsrechts in Europa, Die öffentliche Verwaltung (1999) 1026.
} 
towards international law; what could be learnt from other orders; what the repercussions are of a greater Völkerrechtsfreundlichkeit (kindness or openness towards international law) on the national order, in particular as to the human rights guarantees; and how a national order could be improved in order to become more receptive for the dynamics of international law, which should eventually also strengthen national constitutional guarantees. And there is an additional goal that such a comparative approach should further, namely a better knowledge of international law and the strengthening of a common perspective on this order, where, at the moment, on many issues opinions widely diverge.

In this sense, the contributions presented in this book are to be seen as a first step in a broader, longer lasting project. The selection of the national international law traditions integrated in this book has also to do with the fact that the project was started in Innsbruck, a place where different legal families and legal traditions interact. ${ }^{34}$ The consideration of further national perspectives can contribute to broadening the perspective. And the least that can be gained is an overview on the rich panoply of past writings in international law that might be well known within the respective legal system but widely gone lost outside it even though a closer look at these contributions might reveal a real international relevance. Writing on international law has become so rich and so dense, and it relates to so large time spans that thinking in national legal traditions might be a further tool to structure this enormous knowledge and to keep this information manageable notwithstanding the fact that the borders of these traditions are, as shown, in no way neat and clear.

Nonetheless, as to the Europeanness of the approaches presented here, no doubts can exist. As pointed out in the introductory part to this chapter, to consider a national approach to be "European", traces of "Europeanness" suffice, and they surely abound in the chapters presented here. And within these "traces of Europeanness", we find further "traces of national legal traditions" that make these national traditions identifiable and distinguishable. They reconnect to historical legal identities, and at the same time they adumbrate possible future developments, directions towards which these orders could orient themselves, even though the ongoing European integration may make the borders between these traditions ever more blurry and at the same time the elements of "Europeanness" ever more preponderant. It shall not go unmentioned that for some, this amalgam of national law, international law and European law should be taken as an example also outside the European region as it is designed, first of all, to strengthen international law. ${ }^{35}$

As already hinted at, these contributions are also to be seen as an attempt to further comparative international law. Already some decades ago, very optimistic predictions have been uttered both as to the potential lying inside this approach and

\footnotetext{
${ }^{34}$ As might be known, at the University of Innsbruck both Austrian law as well as Italian law is taught. Furthermore, due to the closeness of Germany and Liechtenstein and the presence of many students from these countries at the University of Innsbruck, research and teaching is done also in German law and in the law of Liechtenstein.

${ }^{35}$ Anne-Marie Slaughter/William Burke-White, 'The Future of International Law is Domestic (or, The European Way of Law)’ (2006) 47 HarvIntlLJ 327.
} 
as to the probability that this potential would materialize. ${ }^{36}$ Seen from hindsight, these forecasts may have been somewhat overenthusiastic, but nonetheless it appears safe to say that comparative international law is here to stay. Publications continue to appear in this field, ${ }^{37}$ and the research interest in this area is continuously growing. It has been defined as a branch of law that "entails identifying, analysing, and explaining similarities and differences in how actors in different legal systems understand, interpret, apply and approach international law". 38

This was exactly the aim of the contributions brought together in this volume. Some contributions concentrate comprehensively on international law approaches of single national legal orders; others take a more specific approach and refer to criminal law or international economic law.

As to the further substantive aim of this inquiry, the basic assumption was that much was gained already by raising awareness about the many differences and similarities between the different national attitudes towards international law. As a further step, it was also tried to explain the similarities and differences previously identified.

Of course, the resulting assessments will always bear a considerable amount of subjective elements, and they therefore will always tell also much about the personal approach to international law by the individual author. Nonetheless, they should at least offer a broad basis for discussion and a plethora of elements that the reader can further work on.

On a whole, this project can only be seen as "research in progress", an endeavour that should bring to light insights of the past that are often astonishingly modern and at the same time also provide tools to refine the common language of international law so that its speakers, whatever their native language is, might be strengthened in their conviction to work on a common, universal project.

A publication on a subject like this, for the time being, can only be eclectic. ${ }^{39}$ Some readers might opine that he or she would have wished to read further analyses about other European international law traditions. And, in fact, this publication is intended only to be a first initiative in a longer lasting project that shall, step by step, integrate further perspectives. Thus, this collection of essays is not "complete", and neither an enlarged second or third edition will be. Nonetheless, this editor hopes that these contributions can give further insights and provide a stimulus for further discussion on comparative international law in general and on European international law traditions in the specific.

\footnotetext{
${ }^{36}$ See William E. Butler (supra, note 24, 2): “[ . . . I venture to suggest that comparative legal studies will increasingly come to be regarded as being as essential to the training of the international lawyer as is the study of international law itself". This event Butler foresaw in 1980 for the future has not yet become reality.

${ }^{37}$ See, for a recent important publication in this field, Anthea Roberts et al. (eds.), Comparative International Law, OUP: New York 2018.

${ }^{38}$ Ibid., 14.

${ }^{39}$ The editors of the book "Comparative International Law" (A. Roberts et al. eds., 2018) even stated that their publication was "intentionally eclectic" (at 31).
} 
As has been aptly said, tradition is weak where it is most actively discussed and inversely strong where it is unspoken of, and even unthinkable to be spoken of (E. Weil, cited by A. Hamann in this book at note 157). This paradox holds not only true from a national perspective. Also in international law, if we compare national traditions, this is not done, as some might fear, to strengthen these traditions (thereby undermining international law as a unitary system) but rather to better understand how international law operates and is being applied. Furthermore, this approach helps to identify misunderstandings and difficulties in international relations resulting from different "historically conditional attitudes" allowing thereby also to overcome these differences. These different traditions need not to be abandoned; it suffices if they are properly understood. A working system of international law does not need to be based on uniform rules of transposition and implementation. A detailed understanding of these national differences might provide the basis to better explain the universal order as a whole, to create transparency as to national barriers that need to be eradicated by amendment and to provide tools permitting an interpretative harmonization of remaining obstacles of lesser dimension. Far from fostering compartmentalization of international law, the identification of and the engagement with different international law traditions might therefore be a potent instrument to further strengthen international law as an effective, internationally accepted, recognized and obeyed legal order.

\section{References}

Anthea R et al. (eds.), Comparative International Law (OUP 2018).

Becker-Lorca A, 'Eurocentrism in the History of International Law' in Bardo Fassbender/Anne Peters (eds.), The Oxford Handbook of the History of International Law (OUP 2012) 1034.

Becker-Lorca A, Mestizo International Law: A Global Intellectual History (1842-1933) (CUP 2015).

Berman H J, 'The Western Legal Tradition in a Millennial Perspective: Past and Future' (2000) 60 La. L. Rev. 740.

Boisson de Chazournes L, 'International economic law and the quest for universality' (2019) 32 Leiden Journal of International Law 401, 413.

Burke E, Reflections on the Revolution in France, 1790 (Pb. edition OUP 2009).

Butler W E, International Law in Comparative Perspective (Brill 1980).

Cassese S (ed.), Research Handbook of Global Administrative Law (Edward Elgar 2016).

Chesterman S et al. (eds.), The Oxford Handbook of United Nations Treaties (OUP 2019).

De Chazournes L B, 'International economic law and the quest for universality' (2019) 32 LJIL 401, 413.

Dumberry P, 'Incoherent and Ineffective: The Concept of Persistent Objector Revisited' (2010) 59 ICLQ 2010779.

Duve T, 'Legal traditions: A dialogue between comparative law and comparative legal history' (2018) 6 Comparative Legal History 20.

Fragmentation of International Law: Difficulties from the Diversification and Expansion of International Law, Report of the Study Group of the International Law Commission (ILC), finalized by Martti Koskenniemi, UN Doc. A/CN.4/L/682 (2006).

Glenn P, 'Comparative Legal Families and Comparative Legal Traditions' in: Mathias Reimann/ Reinhard Zimmermann (eds.), The Oxford Handbook of Comparative Law (OUP 2006a) 424. 
Glenn P, Legal Traditions of the World ( $2^{\text {nd }}$ edition, OUP 2006b).

Heringa A W, Constitutions Compared ( $5^{\text {th }}$ edition, Intersentia 2019).

Hilpold P, 'Ukraine, Crimea and New International Law: Balancing International Law with Arguments Drawn from History’ (2015) 14 Chinese JIL 237.

Issaeva M, 'A Quarter of a Century on from the Soviet Era: Reflections on Russian - Doctrinal Responses to the Annexation of Crimea' in Wladyslav Czaplinski (ed.), The Case of Crimea's Annexation under International Law (Wydawnictwo Naukowe Scholar 2017) 155.

Janis M W, 'Comparative approaches to the theory of international law' (1986) 80 ASIL 152.

Jessup P C, Transnational Law (Yale University Press 1956).

Kennedy D, 'The Disciplines of International Law and Policy' (1999) 12 Leiden Journal of International Law, 19.

Korhonen O, 'Innovative International Law Approaches and the European Condition' in José María Beneyto/David Kennedy (eds.), New Approaches to International Law (T.M.C. Asser Press 2012).

Koskenniemi M, 'International Law in Europe: Between Traditional and Renewal' (2005) 16 EJIL 113.

Mälksoo L, 'Rossiiskaya doktrina mezhdunarodnogo prava' (2013) 58 Evraziiskii iuridicheskii zhurnal 19.

Merryman J and Pérez-Perdomo R, The Civil Law Tradition: An Introduction to the Legal Systems of Europe and Latin America (4 ${ }^{\text {th }}$ edition, Stanford University Press 2018).

Orakhelashvili A, 'The Idea of European International Law' (2006) 17 EJIL 315.

Petersmann E U, Cremona M, Hilpold P, Lavranos N, Staiger Schneider S and Ziegler A R, Reflections on the Constitutionalisation of International Economic Law (Liber Amicorum for Ernst-Ulrich Petersmann, Brill/Martinus Nijhoff 2014).

Picker C B, 'International Law's Mixed Heritage: A Common/Civil Law Jurisdiction' (2008) 41 VandJTransnatlL 1083.

Ruiz Fabri H, 'Reflections on the Necessity of Regional Approaches to International Law Through the Prism of the European Example: Neither Yes nor No, Neither Black nor White' (2011) 1 Asian Journal of International Law 84.

Schachter O, 'The Invisible College of International Lawyers' (1977) 72 Nw.U.L. Rev. 217.

Slaughter A-M and Burke-White W, 'The Future of International Law is Domestic (or, The European Way of Law)' (2006) 47 HarvIntlLJ 327.

Sommermann K-P, 'Die Bedeutung der Rechtsvergleichung für die Fortentwicklung des staats- und Verwaltungsrechts in Europa' (1999) 52 Die öffentliche Verwaltung 1026.

Wood M, 'A European Vision of International Law: For What Purpose?' in: Hélène Ruiz Fabri et al. (eds.), 1 Select Proceedings of the European Society of International Law (2008) 151.

Zartner Falstrom D, 'Thought Versus Action: The Influence of Legal Tradition on French and American Approaches to International Law' (2006) 58 Maine L. Rev. 292.

Open Access This chapter is licensed under the terms of the Creative Commons Attribution 4.0 International License (http://creativecommons.org/licenses/by/4.0/), which permits use, sharing, adaptation, distribution and reproduction in any medium or format, as long as you give appropriate credit to the original author(s) and the source, provide a link to the Creative Commons license and indicate if changes were made.

The images or other third party material in this chapter are included in the chapter's Creative Commons license, unless indicated otherwise in a credit line to the material. If material is not included in the chapter's Creative Commons license and your intended use is not permitted by statutory regulation or exceeds the permitted use, you will need to obtain permission directly from the copyright holder.

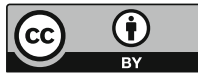

